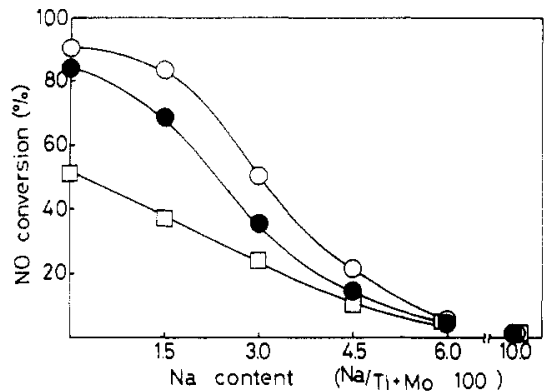

Figure 9. The effect of alkali poisoning of $\mathrm{MoO}_{x}-\mathrm{TiO}_{2} \mathrm{I}$ on the catalytic activity: $\mathrm{MoO}_{x}$ content, 10 atomic $\%$; reaction temperature; 口, $250^{\circ} \mathrm{C} ; \bullet, 275^{\circ} \mathrm{C} ; \mathrm{O}, 300^{\circ} \mathrm{C}$.

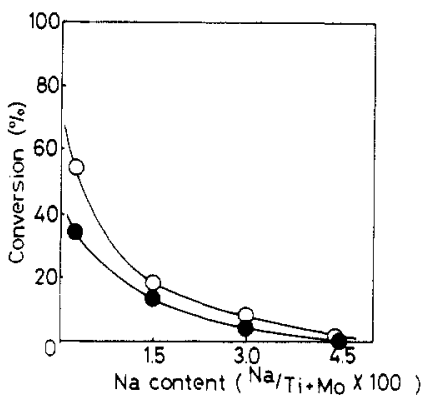

Figure 10. The effect of alkali poisoning of $\mathrm{MoO}_{3}-\mathrm{TiO}_{2} \mathrm{I}$ on the catalytic activity in the isomerization of cyclopropane: 0,3 rd pulse; -, 10th pulse.

the catalytic activity for the reduction of $\mathrm{NO}$ with $\mathrm{NH}_{3}$ was examined. As shown in Figure 9, the activity was decreased with the increase of added amount of $\mathrm{NaOH}$ and almost lost by the addition of 6 atomic $\%$ of $\mathrm{NaOH}$. Thus, the surface acidity seems to play an important role for the reaction of $\mathrm{NO}$ with $\mathrm{NH}_{3}$. To distinguish between Brönsted and Lewis acid sites, the effect of alkali poisoning of $\mathrm{MoO}_{x}-\mathrm{TiO}_{2} \mathrm{I}$ on the activity for the isomerization of cyclopropane to propylene which is known to be catalyzed by Brönsted acids (Jacono and Hall, 1977) was studied. As shown in Figure 10, the activity decreased with the increase of an added amount of $\mathrm{Na}$ and was finally lost. Since the curve of the activity decrease in the isomerization (Figure 10) is similar to that in NO reduction (Figure 9), the acid sites which are active for the reduction seem to be mainly Brönsted type. Takagi et al. (1979) reported from an infrared study that $\mathrm{NH}_{4}{ }^{+}$formed during the reaction of $\mathrm{NO}$ with $\mathrm{NH}_{3}$ on the surface of $\mathrm{VO}_{x}-\mathrm{Al}_{\mathrm{i}} \mathrm{O}_{3}$ is a reactive species. In the present case, the Brönsted acid sites evidenced by infrared study of adsorbed pyridine and the poisoning experiment with alkali for the isomerization of cyclopropane may enhance the activity by facilitating the adsorption of $\mathrm{NH}_{3}$ and the formation of $\mathrm{NH}_{4}{ }^{+}$. It is concluded that the increase of acidity on the addition of $\mathrm{SO}_{4}{ }^{2-}$ and on mixing with $\mathrm{MoO}_{x}$ is vitally important for the activity enhancement.

\section{Literature Cited}

Arata, K.; Hino, M. J. Am. Chem. Soc. 1979, 101, 6439.

Chinone T.; Okazaki, S. Nippon Kagaku Kaishi, 1978, 1327.

Jacono, L.; Hall, W. K. J. Colloid Interface Scl. 1977, 58, 76.

Kazusaka, A.; Watanabe, T.; Miyahara, K.; Tanaka, K.; Tanabe, K. J. Chem. Phys. 1977, 50, 491.

Kurosaki, A.; Ókazaki, S. Nippon Kagaku Kalshi, $1977,1794$.

Nishimura, Y. Fuel Combust. 1978, 45, 9; Japanese Patents, Application No., 50-51966, 1975; 50-65466, 1975; 50-65467, 1975; 51-58411, 1976 [Mitsubishi Chem. Ind. Ltd.]; 50-89264, 1975 [Mitsublshl Petrochemical Co. Ltd.]; 50-89289, 1975; 50-89290, 1975; 50-89291, 1975 [Hltachl Ltd.].

Okazaki, S.; Chinone, T.; Kurosaki, A. Nippon Kagaku Kaishl, 1977, 1282. Okazakl, S.; Ohsuka, N.; lizuka, T.; Tanabe, K. J. Chem. Soc. Chem. Commun. 1976, 654

Primet, M.; Pichat, P.; Mathieu, M. V. J. Phys. Chem. 1971, 75, 1221.

Takagi, M.; Kawai, T.; Soma, M.; Ohnishi, T.; Tamaru, K. J. Catal. 1979, 50, 441.

Tanabe, K.; Itoh, M.; Morishige, K.; Hattori, H. "Preparation of Catalysts", Delmon, B.; Jacobs, P. A.; Poncelet, G. Ed.; Elsevier: Amsterdam, 1976; p 65 .

Received for review August 29, 1980 Accepted January 29, 1981

This work was supported by a Grant-in-Aid (No. 203001) for Scientific Research from the Ministry of Education, Japan.

\title{
Vanadium Oxide Monolayer Catalysts. 4. The Catalytic Oxidation of Carbon Monoxide
}

\author{
Fred Roozeboom, ${ }^{* 1}$ A. Jos van Dillen, ${ }^{2}$ John W. Geus, ${ }^{2}$ and Paul J. Gellings ${ }^{1}$ \\ Twente University of Technology, Depertment of Chemlcal Technology, P.O. Box 217, 7500 AE Enschede, The Netherlands, \\ and State University of Utrecht, Inorganic Chemistry Department, Croesestraat 77A, 3522 AD Utrecht, The Netherlands
}

\begin{abstract}
The oxidation of $\mathrm{CO}$ over vanadium oxide, unsupported and supported as a monolayer (or monomolecular dispersion) on $\gamma-\mathrm{Al}_{2} \mathrm{O}_{3}, \mathrm{CeO}_{2}, \mathrm{TiO}_{2}$, and $\mathrm{ZrO}_{2}$ was studied between 600 and $800 \mathrm{~K}$ in a continuous flow reactor. From catalytic and structural studies it was concluded that the activity of unsupported $\mathrm{V}_{2} \mathrm{O}_{5}$ is determined by its crystallinity, while that of supported vanadlum oxide is affected by interactions with the support. An additional thermogravimetric investigation supports the conclusion that on all catalysts $\mathrm{CO}$ reacts to $\mathrm{CO}_{2}$ via a reduction-oxidation mechanism in which the reduction of the catalyst is the rate-determining step.
\end{abstract}

\section{Introduction}

The interaction between two adhering oxides can in general be expected to be stronger than that between a

* Present address: Exxon Research and Development Labs., P.O. Box 2226, Baton Rouge, LA 70821.

${ }^{1}$ Twente University of Technology.

${ }^{2}$ State University of Utrecht. metal and an oxide. Consequently, the catalytic properties of an active oxide can be expected to be affected appreciably by the support. Because vanadium oxides are used extensively in catalytic oxidation (Dadyburjor et al., 1979) investigation of the effect of the support on its catalytic properties is worthwhile.

Recently, Goldwasser and Trimm (1979) studied the activity of vanadia supported on $\gamma-\mathrm{Al}_{2} \mathrm{O}_{3}, \mathrm{ZrO}_{2}, \mathrm{SiO}_{2}$ for 
the oxidation of $\mathrm{CO}$ and observed a decrease in activity in this order. It is interesting to extend the range of supports and to compare the activity of supported with that of unsupported vanadia catalysts.

In the oxidation of organic molecules it has been observed (Andreikov et al., 1973; Kera and Kuwata, 1979; Shaprinskaya et al. 1970; Stasevich et al., 1969; Simard et al., 1955) that active vanadia catalysts contain vanadium ions with a valency lower than 5 . The partial reduction of active vanadia catalysts has been attributed to a Mars-van Krevelen or reduction-oxidation mechanism (Hughes and Hill, 1955; Hirota et al., 1968; Kera and Hirota, 1969) in which the catalyst is alternately reduced and reoxidized according to the reaction scheme

$$
\begin{gathered}
\mathrm{M}+\mathrm{O}_{\mathrm{act}} \rightarrow \text { "MO" }+\mathrm{V}_{0} \\
\mathrm{~V}_{0}+1 / 2 \mathrm{O}_{2} \rightarrow \mathrm{O}_{\text {act }}
\end{gathered}
$$

where $\mathrm{M}$ is the molecule oxidized to products symbolized by "MO", $\mathrm{O}_{\text {act }}$ is the active oxygen species of the catalyst, and $V_{0}$ is a surface oxygen vacancy.

Other evidence for this type of mechanism is that, in the absence of gaseous oxygen, the oxidation proceeds with the same selectivity as in its presence, though only for a short time. The evidence concerning the oxidation of $\mathrm{H}_{2}$ and $\mathrm{CO}$ is less clear cut (Van Dillen, 1977). Some authors (Marshneva et al., 1972) have put forward evidence pointing to an associative mechanism, where lattice oxygen does not participate, while others (Hirota et al., 1968; Kera and Hirota, 1969; Hughes and Hill, 1955) prefer a reduction-oxidation mechanism.

In this work the effects of $\gamma-\mathrm{Al}_{2} \mathrm{O}_{3}, \mathrm{ZrO}_{2}, \mathrm{TiO}_{2}$, and $\mathrm{CeO}_{2}$ as supports on the activity of vanadia in the oxidation of $\mathrm{CO}$ were studied. Because the interaction between vanadia and the support may be influenced by the valence state of the vanadium these activities have also been studied after an intermediate reduction $\left(\right.$ by $\mathrm{H}_{2}$ ) and reoxidation treatment. Before this reduction-reoxidation treatment the supports were covered by approximately a monolayer of vanadia (Roozeboom et al., part 1, 1979; part 2, 1978; part 3, 1980, part 5, 1981).

As evidence has been published (Tilley and Hyde, 1970) that the crystal size and defect structure of vanadium pentoxide affect its reducibility, two types of unsupported $\mathrm{V}_{2} \mathrm{O}_{5}$ were also studied.

Comparison of the catalytic properties of the different unsupported and supported vanadia catalysts made it possible to discriminate between effects of particle size and defect structure on the one hand, and those of a chemical interaction with the supports on the other.

To investigate whether a connection exists between the catalytic activity in $\mathrm{CO}$ oxidation and the reducibility of the vanadia, the catalysts have also been studied by temperature programmed reduction.

\section{Experimental Section}

Materials. Two different unsupported $\mathrm{V}_{2} \mathrm{O}_{5}$ catalysts were used: a Baker product (analytical grade), which was annealed at elevated temperatures, and a catalyst prepared by decomposition of $\mathrm{NH}_{4} \mathrm{VO}_{3}$ (Merck, analytical grade). This was performed at a relatively low temperature by heating at $600 \mathrm{~K}$ for $2 \mathrm{~h}$ in a stream of air.

The oxidic carriers, viz., $\gamma-\mathrm{Al}_{2} \mathrm{O}_{3}, \mathrm{CeO}_{2}, \mathrm{TiO}_{2}$, and $\mathrm{ZrO}_{2}$ have previously been described (Roozeboom et al., 1978, 1979). All gases (Loosco, Amsterdam) were dried by BDH molecular sieve Type 4A. Nitrogen and argon were deoxygenated by BTS-catalyst R-3-11 (BASF). Hydrogen was deoxygenated by a Baker "deoxy" catalyst $\left(\mathrm{Pd} / \mathrm{Al}_{2} \mathrm{O}_{3}\right)$.

Catalyst Preparation. The supported vanadia catalysts were prepared by passing a freshly prepared aqueous solution of 1 wt \% ammonium vanadate (acidified with $\mathrm{HNO}_{3}$ to $\mathrm{pH}$ 4) through a bed of particles of the support (0.3-0.6 mm diameter). For further details see part 1 of this series (Roozeboom et al., 1979). The catalysts were dried at $383 \mathrm{~K}(17 \mathrm{~h})$ and calcined at $723 \mathrm{~K}(2 \mathrm{~h})$.

$\mathrm{X}$-ray Fluorescence. The vanadium content of the catalyst samples was determined with a Philips $1410 \mathrm{X}$-ray spectrometer by X-ray fluorescence (Van Willigen et al., 1971).

X-ray Diffraction. The two types of unsupported $\mathrm{V}_{2} \mathrm{O}_{5}$ were analyzed with a Philips PW 1050-25 vertical diffractometer.

Temperature-Programmed Reduction. TPR profiles of the two unsupported $\mathrm{V}_{2} \mathrm{O}_{5}$ catalysts were recorded by the procedure described in part 3 (Roozeboom et al., 1980).

Thermogravimetry (TG). This was carried out by means of a Mettler Thermoanalyzer with which weight changes (accuracy: $0.02 \mathrm{mg}$ ) were continuously recorded. In order to eliminate gas flow and buoyancy effects, blank runs with an empty crucible were performed prior to each measurement. In most cases approximately $70 \mathrm{mg}$ of catalyst was brought into an inert alumina sample holder (Type ME-93523). An argon flow of $50 \mathrm{~mL}$ NTP $\mathrm{min}^{-1}$ was passed through the housing of the balance as a protective measure. Oxygen and hydrogen were fed into the furnace surrounding the specimen.

Each sample successively underwent three treatments during which its weight was recorded while the temperature was increased from room temperature to $830 \mathrm{~K}$ at a rate of $5 \mathrm{~K} \mathrm{~min}^{-1}$. The treatments were: (i) dehydration in an oxygen flow (10 mL NTP $\mathrm{min}^{-1}$; (ii) after flushing with argon to remove the oxygen: reduction in a hydrogen flow (10 $\mathrm{mL}$ NTP $\mathrm{min}^{-1}$; (iii) after flushing with argon: reoxidation in an oxygen flow $\left(10 \mathrm{~mL} \mathrm{NTP} \mathrm{min}^{-1}\right)$. If required, the temperature in step (ii) was kept at the maximum value of $830 \mathrm{~K}$ in order to complete reduction.

Catalytic Measurements. The oxidation of $\mathrm{CO}$ was studied in a conventional flow reactor as described elsewhere (Van Dillen, 1977). The reactor was kept at a pre-set temperature within $\pm 1 \mathrm{~K}$. The gas feed usually contained 1 vol $\% \mathrm{CO}, 1 \mathrm{vol} \% \mathrm{O}_{2}$, and $98 \mathrm{vol} \% \mathrm{~N}_{2}$ at a total gas flow of $50 \mathrm{~mL}$ NTP $\mathrm{min}^{-1}$. The determination of the $\mathrm{CO}_{2}$ formed was based on the change in electric conductivity of an aqueous $\mathrm{NaOH}$ solution, using complete oxidation of CO over a BTS catalyst as a reference for $100 \%$ conversion.

\section{Experimental Results}

Thermogravimetry. One of the questions to be answered in establishing a mechanism for catalytic oxidation reactions concerns the relative ease of reduction and reoxidation of the catalyst. Therefore, a thermogravimetric study was performed on all supported vanadia catalysts used in this investigation. As an example Figure 1 gives the TG curves obtained during reduction (after previous dehydration) and subsequent reoxidation of vanadia on $\mathrm{ZrO}_{2}$. These are typical for the curves obtained with all catalysts. All TG-data are collected in Table I and it is clear that the reduction of all catalysts sets in at considerably higher temperatures than their reoxidation. This is in agreement with the results of Van Dillen (1977) on unsupported $\mathrm{V}_{2} \mathrm{O}_{5}$ (a Baker product) for which reduction started at $733 \mathrm{~K}$ and reoxidation already at $393 \mathrm{~K}$.

The weight changes show that the vanadium is reduced to the trivalent state and that the reoxidation restores the original pentavalent state. Only on $\gamma-\mathrm{Al}_{2} \mathrm{O}_{3}$ the weight loss would imply reduction to the quadrivalent state, which, however, is not in agreement with TPR results reported 
Table I. Results of Thermogravimetric Experiments

\begin{tabular}{|c|c|c|c|c|}
\hline & $\mathrm{V} / \gamma-\mathrm{Al}_{2} \mathrm{O}_{3}$ & $\mathrm{~V} / \mathrm{CeO}_{2}$ & $\mathrm{~V} / \mathrm{TiO}_{2}$ & $\mathrm{~V} / \mathrm{ZrO}_{2}$ \\
\hline $\begin{array}{l}\text { wt } \% \text { V (XRF analysis) } \\
\text { starting weight, } \mathrm{mg}\end{array}$ & $\begin{array}{c}6.8 \\
79.85\end{array}$ & $\begin{array}{c}5.3 \\
76.85\end{array}$ & $\begin{array}{l}1.7 \\
71.58\end{array}$ & $\begin{array}{c}4.3 \\
74.86\end{array}$ \\
\hline \multicolumn{5}{|c|}{ Dehydration } \\
\hline weight loss, mg & 4.75 & 2.56 & 1.58 & 5.26 \\
\hline $\begin{array}{l}\text { temperature of onset of reduction, } \mathrm{K} \\
\text { weight loss, mg } \\
\text { wt } \% \text { (from TG-analysis) }^{a}\end{array}$ & $\begin{array}{l}\text { Reduction } \\
633 \\
0.77 \\
3.1\end{array}$ & $\begin{array}{l}633 \\
1.43 \\
5.9\end{array}$ & $\begin{array}{l}593 \\
\quad 0.54 \\
2.4\end{array}$ & $\begin{array}{l}453 \\
\quad 1.06 \\
4.5\end{array}$ \\
\hline $\begin{array}{l}\text { temperature of onset of reoxidation, } \mathrm{K} \\
\text { temperature of complete reoxidation, } \mathrm{K} \\
\text { weight change, } \mathrm{mg}\end{array}$ & $\begin{array}{l}\text { Reoxidatior } \\
\leqslant 303 \\
613 \\
0.73\end{array}$ & $\begin{array}{l}\leqslant 303 \\
513 \\
1.45\end{array}$ & $\begin{array}{l}\leqslant 303 \\
673 \\
0.60\end{array}$ & $\begin{array}{l}\leqslant 303 \\
583 \\
1.04\end{array}$ \\
\hline
\end{tabular}

${ }^{a}$ Based on the assumption that $\mathrm{V}^{5+}$ is reduced to $\mathrm{V}^{3+}$ (Roozeboom et al., part 3,1980 ).
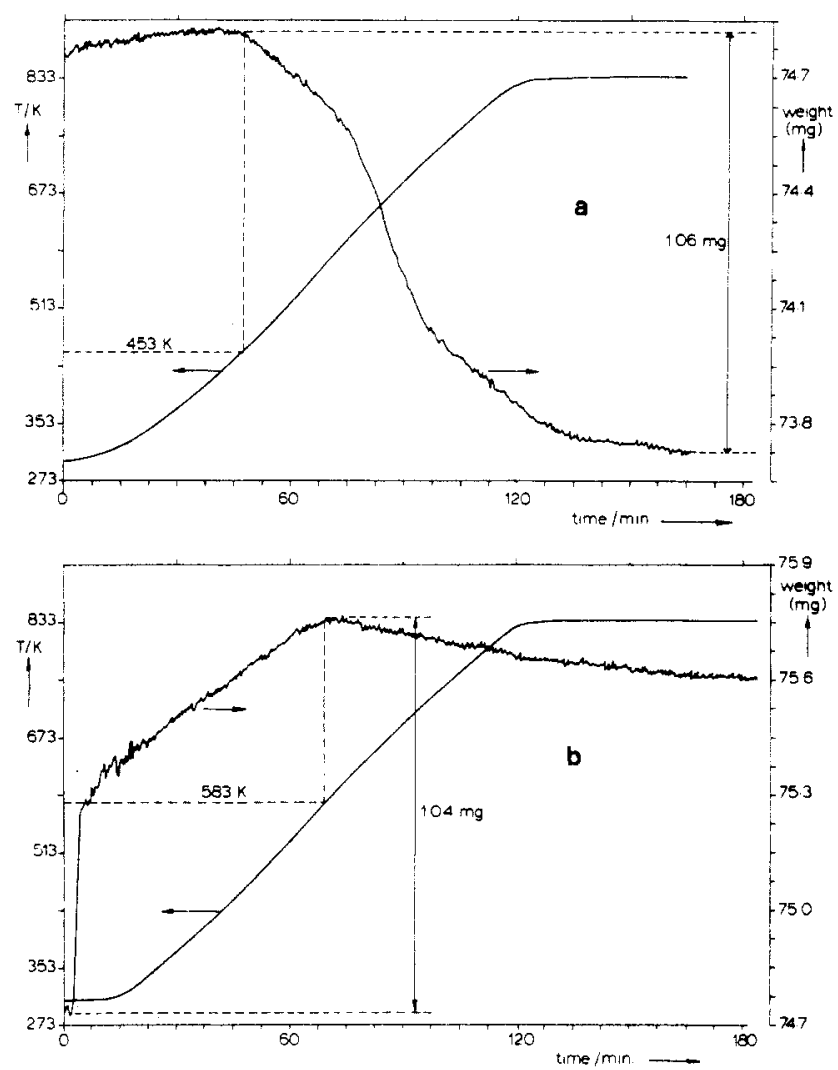

Figure 1. TG curves for vanadium oxide on $\mathrm{ZrO}_{2}$ : a, weight decrease during reduction; $b$, weight increase during reoxidation. (Note: the starting weight of the sample is equal for both cases only for arbitrary computer programmation reasons).

in part 3 (Roozeboom et al., 1980). As yet no explanation can be given for this discrepancy.

Above the temperatures at which reoxidation is complete a very small weight loss is noted. This might be due to some decomposition of the supported vanadia to some suboxide such as $\mathrm{V}_{3} \mathrm{O}_{7}$ or $\mathrm{V}_{6} \mathrm{O}_{13}$. Unfortunately, no thermodynamic data are available to substantiate this possibility (decomposition to, e.g., $\mathrm{VO}_{2}$ would not be expected to occur at temperatures below $1200-1400 \mathrm{~K}$ ).

Temperature-Programmed Reduction. Because crystallite size has been shown to play an important role in the reduction of vanadia (Tilley and Hyde, 1970) and to allow a comparison with earlier TPR measurements on supported catalysts (Roozeboom et al., part 3, 1980), TPR measurements were performed on pure $\mathrm{V}_{2} \mathrm{O}_{5}$. These were done with well-annealed $\mathrm{V}_{2} \mathrm{O}_{5}$ and with $\mathrm{V}_{2} \mathrm{O}_{5}$ freshly prepared by thermal decomposition of $\mathrm{NH}_{4} \mathrm{VO}_{3}$. The re-

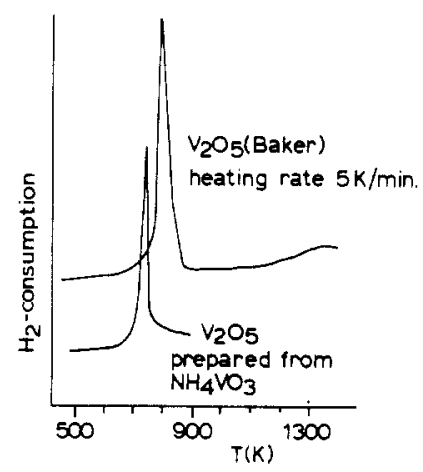

Figure 2. TPR profiles of the two types of $\mathrm{V}_{2} \mathrm{O}_{5}$.

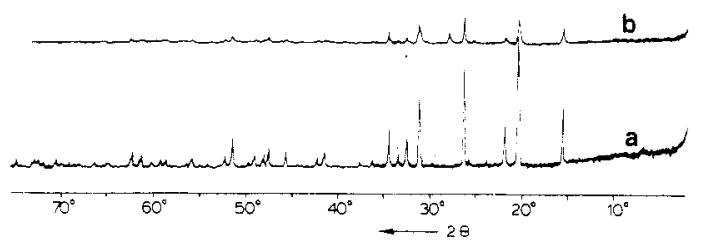

Figure 3. X-ray diffraction patterns of (a) well annealed $\mathrm{V}_{2} \mathrm{O}_{5}$ (Baker) and (b) freshly prepared $\mathrm{V}_{2} \mathrm{O}_{5}$.

sulting TPR curves in Figure 2 show that the reduction of the well-annealed $\mathrm{V}_{2} \mathrm{O}_{5}$ starts at $725 \mathrm{~K}$, whereas that of the freshly prepared $\mathrm{V}_{2} \mathrm{O}_{5}$ starts at $675 \mathrm{~K}$. This is only slightly higher than that of a monolayer of $\mathrm{V}_{2} \mathrm{O}_{5}$ on $\gamma-\mathrm{Al}_{2} \mathrm{O}_{3}$ (Roozeboom et al., part 3, 1980).

The X-ray diffraction patterns shown in Figure 3 show that in the freshly prepared $\mathrm{V}_{2} \mathrm{O}_{5}$ a very small amount of suboxide is present (both $\mathrm{V}_{2} \mathrm{O}_{4}$ and $\mathrm{V}_{6} \mathrm{O}_{13}$ have their strongest XRD line near $2 \theta=28^{\circ}$ ). This indicates that the freshly prepared $\mathrm{V}_{2} \mathrm{O}_{5}$ contains a large number of defects and these may well cause the greater ease of reduction.

On both types of $\mathrm{V}_{2} \mathrm{O}_{5} \mathrm{TG}$ showed again that reoxidation starts at a much lower temperature $(\leq 413 \mathrm{~K})$ than reduction.

Catalytic Studies. Table II summarizes the results of the catalytic experiments. In all cases the order in $\mathrm{CO}$ was found to be 1 or nearly so. The order in oxygen was zero for all catalysts. From the measured conversions the rate constants were calculated by integration. In Figure 4 some typical Arrhenius plots are shown from which the data in Table II were derived.

Repeated experiments on $\mathrm{V}_{2} \mathrm{O}_{5}$ freshly prepared from $\mathrm{NH}_{4} \mathrm{VO}_{3}$ show that after this has been heated to sufficiently high temperatures the activity drops to that of the well-annealed $\mathrm{V}_{2} \mathrm{O}_{5}$ (Baker) with an increase in activation energy and preexponential factor. 
Table II. Results on CO Oxidation, Gas Feed: 1 vol \% CO, 1 vol \% $\mathrm{O}_{2}, 98$ vol \% $\mathrm{N}_{2} ;$ Flow $50 \mathrm{~mL} \mathrm{NTP} \mathrm{min}^{-1}$

\begin{tabular}{|c|c|c|c|c|c|c|c|}
\hline catalyst & $\begin{array}{c}\mathrm{V} \\
\mathrm{wt} \% \\
\end{array}$ & $\begin{array}{c}E_{\mathrm{A}}( \pm 0.5),{ }^{c} \\
\mathrm{kcal} \mathrm{mol}^{-1}\end{array}$ & $\mathrm{~s}^{-1} \mathrm{~m}^{k_{0-2}^{e}}$ cat. & $\begin{array}{c}S_{\mathrm{BET}} \\
\mathrm{m}^{2} \mathrm{~g}^{-1}\end{array}$ & $\begin{array}{l}\text { order } \\
\text { w.r.t. } \\
\text { CO }^{a}\end{array}$ & $\begin{array}{l}\text { order } \\
\text { w.r.t. } \\
\mathrm{O}_{2} b\end{array}$ & $T_{\text {start }}{ }^{d}$ \\
\hline $\begin{array}{l}\mathrm{V}_{2} \mathrm{O}_{5}, \text { stabilized (Baker) } \\
\mathrm{V}_{2} \mathrm{O}_{5} \text {, freshly prepared } \\
\text { (decomp. of } \mathrm{NH}_{4} \mathrm{VO}_{3} \text { ) }\end{array}$ & $\begin{array}{l}56.0 \\
56.0\end{array}$ & $\begin{array}{l}25.7 \\
19.0\end{array}$ & $\begin{array}{l}7 \times 10^{4} \\
3 \times 10^{3}\end{array}$ & $\begin{array}{l}8.2 \\
9.5\end{array}$ & $\begin{array}{l}1.0 \\
1.0\end{array}$ & $\begin{array}{l}0 \\
0\end{array}$ & $\begin{array}{l}770 \\
750\end{array}$ \\
\hline $\begin{array}{l}\mathrm{V} / \gamma-\mathrm{Al}_{2} \mathrm{O}_{3}, \text { before and after several } \\
\text { reduction/reoxidation cycles } f\end{array}$ & 6.8 & 18.6 & $1.5 \times 10^{3}$ & 80 & 0.9 & 0 & 650 \\
\hline $\begin{array}{l}\mathrm{V} / \mathrm{TiO}_{2} \text {, before red./reox. }{ }^{f} \\
\text { after red./reox. } f \\
\text { pure } \mathrm{TiO}_{2}\end{array}$ & 1.7 & $\begin{array}{l}18.6 \\
12.9 \\
12.7\end{array}$ & $\begin{array}{l}2 \times 10^{5} \\
4 \times 10^{2} \\
7 \times 10\end{array}$ & $\begin{array}{r}45 \\
45\end{array}$ & 1.0 & 0 & $\begin{array}{l}600 \\
550 \\
620\end{array}$ \\
\hline $\begin{array}{l}\mathrm{V} / \mathrm{ZrO}_{2} \text {, before and after red./reox. } f \\
\text { pure } \mathrm{ZrO}_{2}\end{array}$ & 4.3 & $\begin{array}{l}14.0 \\
14.0\end{array}$ & $\begin{array}{l}1 \times 10^{3} \\
6 \times 10\end{array}$ & $\begin{array}{l}107 \\
156\end{array}$ & 1.0 & 0 & $\begin{array}{l}520 \\
570\end{array}$ \\
\hline $\begin{array}{l}\mathrm{V} / \mathrm{CeO}_{2} \text {, before red./reox. }{ }^{f} \\
\text { after red./reox. }{ }^{f} \\
\text { pure } \mathrm{CeO}_{2}\end{array}$ & 5.3 & $\begin{array}{l}15.0 \\
15.0 \\
15.0\end{array}$ & $\begin{array}{l}5 \times 10^{2} \\
1 \times 10^{3} \\
6 \times 10^{4}\end{array}$ & $\begin{array}{l}48 \\
48\end{array}$ & 1.0 & 0 & $\begin{array}{l}615 \\
575 \\
475\end{array}$ \\
\hline
\end{tabular}

${ }^{a} 1 \mathrm{vol} \% \mathrm{O}_{2}$ fixed, $0.25-1.5 \mathrm{vol} \% \mathrm{CO} .{ }^{b} 1 \mathrm{vol} \% \mathrm{CO}$ fixed, $0.5-2 \mathrm{vol} \% \mathrm{O}_{2}$. $c$ Temperature range $600-800 \mathrm{~K}$. $d$ Temperature at which $2 \%$ conversion of $\mathrm{CO}$ was observed. ${ }^{e}$ Calculated from measured conversions $(x)$ according to $-\mathrm{ln}(1-x)$ $=k_{0} e^{-E_{\mathrm{A}} / R T}$. This consists of a treatment consisting of reduction by $\mathrm{H}_{2}$ at $800 \mathrm{~K}$ for $1 \mathrm{~h}$, followed by reoxidation by $\mathrm{O}_{2}$ at $800 \mathrm{~K}$ for $1 \mathrm{~h}$. Each reduction and reoxidation was recorded by a hygrometer in order to verify complete reduction.
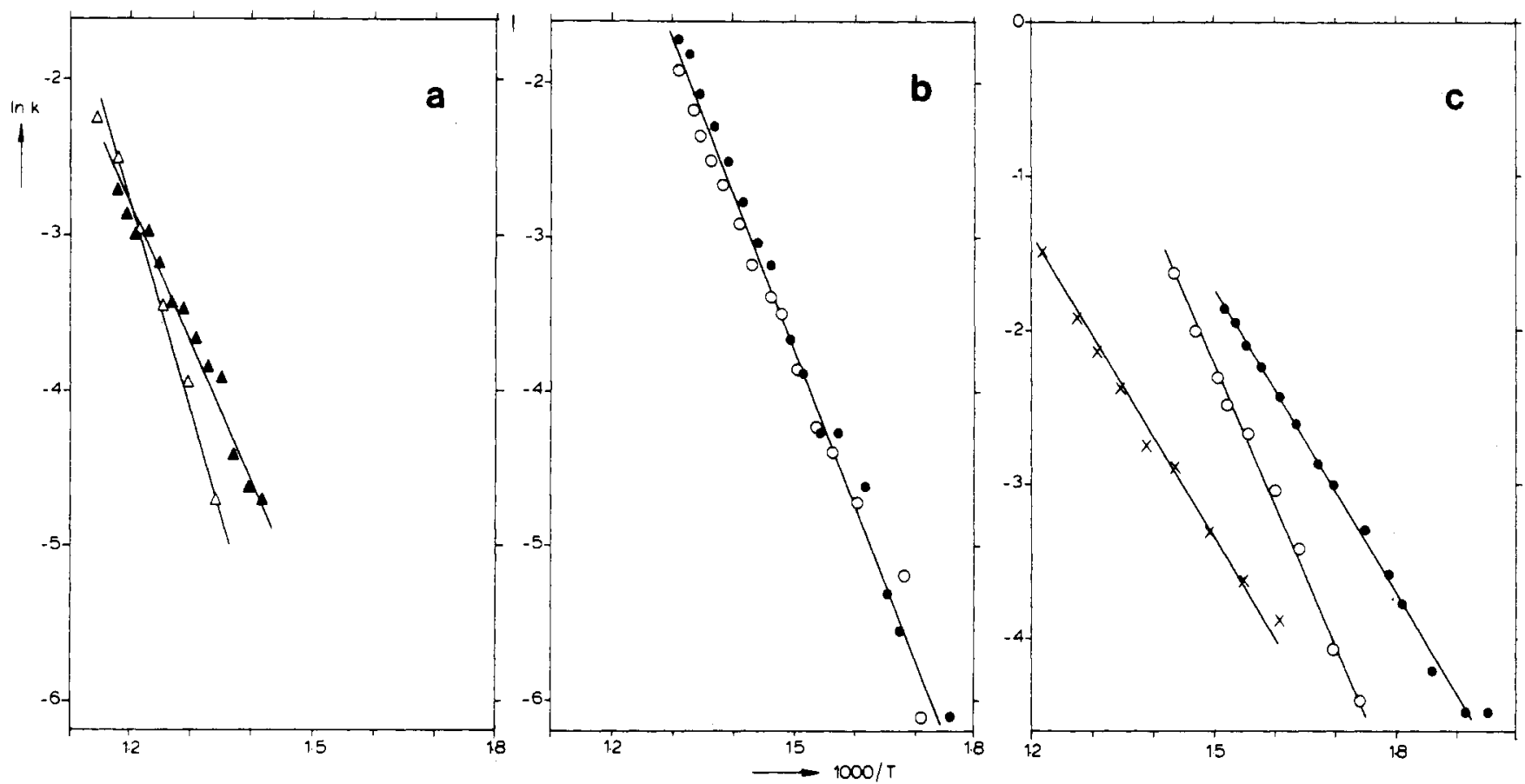

Figure 4. Arrhenius plots of $\mathrm{CO}$ oxidation on: a, well-annealed $(\Delta)$ and freshly prepared $(\Delta) \mathrm{V}_{2} \mathrm{O}_{5} ; \mathrm{b}, \mathrm{V} / \gamma$ - $\mathrm{Al}_{2} \mathrm{O}_{3}$, freshly prepared $(\mathrm{O})$, and after reduction by $\mathrm{H}_{2}$ and reoxidation by $\mathrm{O}_{2}(\bullet) ; \mathrm{c}, \mathrm{V} / \mathrm{TiO}_{2}$, freshly prepared $(\mathrm{O})$ after reduction by $\mathrm{H}_{2}$ and reoxidation by $\mathrm{O}_{2}(\bullet)$ and pure $\mathrm{TiO}_{2}(x)$.

Irreversible changes in the $\mathrm{V}_{2} \mathrm{O}_{5}$ monolayers may be caused by reduction, either due to agglomeration of the vanadia or due to dissolution of vanadium ions in the support. Therefore all supported catalysts were submitted to complete reduction by $\mathrm{H}_{2}$. After reoxidation with oxygen the catalytic activity was measured again. As shown in Table II the catalaytic activity of $\mathrm{V}_{2}^{\prime} \mathrm{O}_{5} / \gamma-\mathrm{Al}_{2} \mathrm{O}_{3}$ and of $\mathrm{V}_{2} \mathrm{O}_{5} / \mathrm{ZrO}_{2}$ is not changed by this treatment. $\mathrm{V}_{2} \mathrm{O}_{5} / \mathrm{TiO}_{2}$, which before reduction/reoxidation behaves similarly to $\mathrm{V}_{2} \mathrm{O}_{5} / \gamma-\mathrm{Al}_{2} \mathrm{O}_{3}$, shows a large change in behavior. The activation energy becomes equal to that of the oxidation of $\mathrm{CO}$ by pure $\mathrm{TiO}_{2}$ but the preexponential factor is significantly greater. For $\mathrm{V}_{2} \mathrm{O}_{5}$ on $\mathrm{CeO}_{2}$ only the preexponential factor is observed to increase after reduction/reoxidation.

Pure $\gamma-\mathrm{Al}_{2} \mathrm{O}_{3}$ shows no catalytic activity in $\mathrm{CO}$ oxidation. The other supports show an activity which increases in the order $\mathrm{ZrO}_{2}<\mathrm{TiO}_{2} \ll \mathrm{CeO}_{2}$.

\section{Discussion}

The observed orders of 1 for $\mathrm{CO}$ and 0 for $\mathrm{O}_{2}$ on all catalysts are in agreement with a reduction-oxidation mechanism in which the reduction of the catalyst by $\mathrm{CO}$ (reaction 1) is rate determining. This is supported completely by the thermogravimetric results which show that reduction of the catalysts is slow and only starts at a relatively high temperature, whereas reoxidation is fast and sets in already at low temperatures.

Furthermore, it is important to note that the temperatures at which reduction starts in the TG experiments are for all catalaysts very close to the temperatures' at which $\mathrm{CO}$ oxidation sets in.

From the catalytic experiments it emerges that three types of active sites can be distinguished in these catalysts: (1) sites with low activity (high activation energy) on well-annealed $\mathrm{V}_{2} \mathrm{O}_{5}$; (2) sites with high activity (intermediate activation energy) on freshly prepared $\mathrm{V}_{2} \mathrm{O}_{5}$ and on 
the $\mathrm{V}_{2} \mathrm{O}_{5}$ monolayers on $\gamma-\mathrm{Al}_{2} \mathrm{O}_{3}$ and, before reduction/ reoxidation, on $\mathrm{TiO}_{2}$; (3) sites with very high activity (low activation energy) on some supports, with or without dissolved vanadium ions.

1. The results obtained with a well-annealed $\mathrm{V}_{2} \mathrm{O}_{5}$ lead to the conclusion that this contains a large number of active sites (high preexponential factor) with a low activity due to the high energy of activation of $25.7 \mathrm{kcal} \mathrm{mol}^{-1}$.

2. The freshly prepared $\mathrm{V}_{2} \mathrm{O}_{5}$ has a higher overall activity than the well-annealed $\mathrm{V}_{2} \mathrm{O}_{5}$ due to a much lower activation energy of $19 \mathrm{kcal} \mathrm{mol}^{-1}$ even though the number of active sites is smaller $\left(k_{0}=3 \times 10^{3} \mathrm{~s}^{-1} \mathrm{~m}^{-2}\right)$.

As is clear from the $\mathrm{X}$-ray diffraction patterns of Figure 3 the well-annealed $\mathrm{V}_{2} \mathrm{O}_{5}$ consists of larger crystallites containing less lattice defects as shown by the sharper and higher diffraction maxima. Thus, in agreement with previous work (Tilley and Hyde, 1970) the rate of reduction of $\mathrm{V}_{2} \mathrm{O}_{5}$ increases with decreasing crystal size, as is shown by the TPR profiles of Figure 2. At the same time this corresponds to a greater activity in $\mathrm{CO}$ oxidation.

Evidently the larger number of lattice defects in the smaller crystallites of freshly prepared $\mathrm{V}_{2} \mathrm{O}_{5}$ causes an acceleration of the nucleation of a reduced phase. Keeping this catalyst at a sufficiently high temperature leads to recrystallization and hence to annihilation of the defects. The catalytic activity consequently becomes more like that of well-annealed $\mathrm{V}_{2} \mathrm{O}_{5}$.

As can be seen from Table II, a monolayer of vanadium oxide on $\gamma-\mathrm{Al}_{2} \mathrm{O}_{3}$ and $\mathrm{TiO}_{2}$ exhibits initially about the same activation energy $\left(18.6 \mathrm{kcal} \mathrm{mol}^{-1}\right)$ as poorly crystallized $\mathrm{V}_{2} \mathrm{O}_{5}\left(19.0 \mathrm{kcal} \mathrm{mol}^{-1}\right)$. With alumina as a support the $k_{0}$ value is of the same order of magnitude $\left(10^{3} \mathrm{~s}^{-1} \mathrm{~m}^{-2}\right)$, whereas with titania it is appreciably higher $\left(2 \times 10^{5} \mathrm{~s}^{-1}\right.$ $\mathrm{m}^{-2}$ ). The agreement in $E_{\mathrm{A}}$ indicates that these catalysts also contain very finely divided vanadia species, containing a large number of lattice defects with a high activity. These species are hardly influenced by a specific interaction with the support, as long as they are present as a monolayer. Evidently this monolayer is very stable on $\gamma$-alumina as shown by the absence of any effect of (hydrogen-) reduction and reoxidation on the catalytic activity of vanadia on $\gamma-\mathrm{Al}_{2} \mathrm{O}_{3}$.

3. Upon reduction-reoxidation the activity of vanadium oxide on titania becomes characteristic of that of pure titania, though with a higher $k_{0}$ value. It is probable that, on reduction treatment, vanadium, probably as $\mathrm{V}^{4+}$ ions, dissolves in the titania, which brings about the disappearance of $V$ oxide from the surface and explains the increased number of active sites on the titania surface (higher $k_{0}$ value).

For vanadia on zirconia and ceria the activation energies are equal to those of the supports irrespective of any reduction-reoxidation treatments.

Like titania, ceria is more active than pure $\mathrm{V}_{2} \mathrm{O}_{5}$. The activities of the pure supports run parallel to the order of their reducibilities: $\mathrm{CeO}_{2} \gg \mathrm{ZrO}_{2} \approx \mathrm{TiO}_{2} \gg \gamma-\mathrm{Al}_{2} \mathrm{O}_{3}$ as determined from TPR experiments (Roozeboom et al., part $3,1980)$.

Deposition of vanadium oxide poisons the activity of ceria. For a reduction-oxidation mechanism this correlates well with the better reducibility of $\mathrm{CeO}_{2}$ as compared with that of $\mathrm{V} / \mathrm{CeO}_{2}$, as shown by means of TPR (Roozeboom et al., part 3, 1980). On reduction-reoxidation some vanadium is probably incorporated in the ceria, thus increasing the uncovered ceria surface, which is more active than $V$ oxide. Since some of the vanadium remains at the surface the $k_{0}$ value of the pure ceria is not obtained. In the case of vanadia on zirconia a strong interaction may

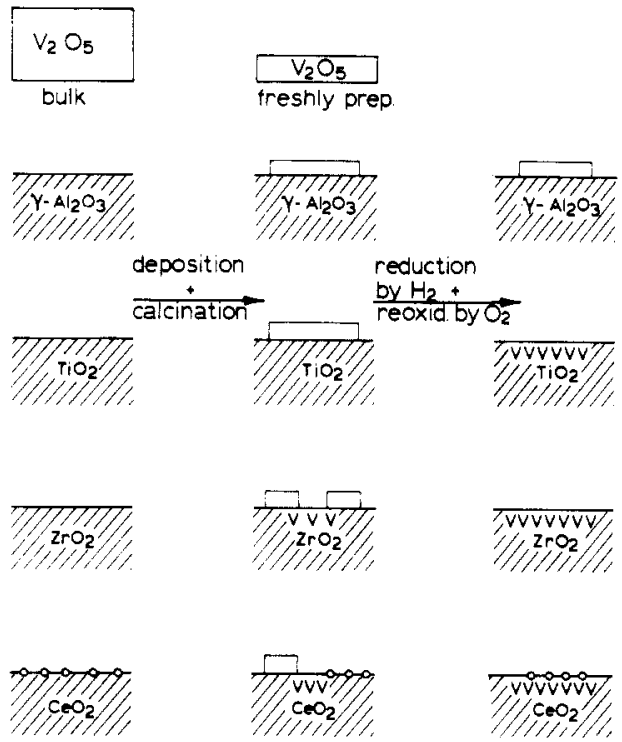

Figure 5. Schematic representation of possible interaction between vanadium oxide and supports. (The circles in $\mathrm{CeO}_{2}$ symbolize the active sites present on pure $\mathrm{CeO}_{2}$ ).

readily cause the formation of a $\mathrm{ZrV}_{2} \mathrm{O}_{7}$-like surface compound already during calcination, the stability of which is reflected by the fact that $E_{\mathrm{A}}$ and $k_{0}$ are not changed by the reduction-reoxidation treatment. Incorporation of vanadium ions into the zirconia lattice leads to an increase in the number of active sites, as observed above with titania.

The above interpretation is in agreement with the structural changes occurring on heat treatment of the monolayer type catalysts reported previously (Roozeboom et al., part 3, 1980): (i) on $\gamma-\mathrm{Al}_{2} \mathrm{O}_{3}$ the vanadia monolayer structure does not change markedly; (ii) on $\mathrm{TiO}_{2}$ a solid solution is formed; (iii) on $\mathrm{ZrO}_{2}$ there is formation of $\mathrm{ZrV}_{2} \mathrm{O}_{7}$ and of a solid solution; (iv) on $\mathrm{CeO}_{2}$ small amounts of $\mathrm{V}$ surface compounds are present. This correlation between the spectroscopic observations of the structural behavior on the one and the catalaytic behavior on the other hand is summarized schematically in Figure 5.

In a recent paper, Goldwasser and Trimm (1979) studied the influence of the support for the $\mathrm{CO}$ oxidation over vanadium oxide supported on $\gamma-\mathrm{Al}_{2} \mathrm{O}_{3}, \mathrm{SiO}_{2}$, and $\mathrm{ZrO}_{2}$. They also concluded that the nature of the support affects the adsorption of gases and the catalytic activity. They reported the activities to decrease in the order $\mathrm{V} / \gamma-\mathrm{Al}_{2} \mathrm{O}_{3}$ $>\mathrm{V} / \mathrm{ZrO}_{2}>\mathrm{V} / \mathrm{SiO}_{2}$, whereas in this study the order $\mathrm{V} /$ $\mathrm{ZrO}_{2}>\mathrm{V} / \mathrm{TiO}_{2}>\mathrm{V} / \mathrm{CeO}_{2}>\mathrm{V} / \gamma-\mathrm{Al}_{2} \mathrm{O}_{3}$ is observed. Goldwasser and Trimm (1979), however, had some difficulties in the study of $\mathrm{V} / \mathrm{ZrO}_{2}$ and report that their method for measuring specific surface areas (based on the oxygen sorption of prereduced catalyst samples at $78 \mathrm{~K}$ ) may not be appropriate in this case. Moreover, their use of XRD in establishing the presence of a monolayer or solid solution is questionable: for XRD crystallites of at least $50 \AA$ (i.e., 10 monolayers) are required. This would contradict their oxygen sorption measurements which point to a monomolecular dispersion.

In the preceding paper (Roozeboom et al., part 3, 1980) it was shown that at low coverages it is impossible to study the dispersed vanadia by XRD, but that Raman spectroscopy and TPR can be used.

Furthermore, the above authors used V coverages far below the theoretical monolayer capacities. On the basis of a surface area of $10.3 \AA^{2}$ per $V_{2.5}$ unit (Hanke et al., 1975 ) and with their catalyst surface areas it can be calculated that they applied only $5.0,1.3$, and $12.5 \%$ of the 
theoretical vanadium oxide monolayer capacity onto alumina, silica, and zirconia, respectively. Thus, especially on zirconia $\mathrm{O}_{2}^{-}$(inactive for $\mathrm{CO}$ oxidation) may be stabilized by spill-over from vanadia to the support (Fenin et al., 1971) and decrease the activity of $\mathrm{V} / \mathrm{ZrO}_{2}$.

\section{Concluding Remarks}

The above consistent evidence has shown that there exists a close correspondence between the structure and the activity of a catalyst.

The activity of unsupported $\mathrm{V}_{2} \mathrm{O}_{5}$ is appreciably determined by its crystallinity, while supported vanadium oxide is substantially affected by its interaction with the support, and two types of active sites can be distinguished in these catalysts.

Vanadium ions dissolving in supports, which are active themselves, may often act as promoters constituting a third type of active site.

On all catalysts $\mathrm{CO}$ reacts to $\mathrm{CO}_{2}$ via a redox mechanism in which the rate-determining step is the reduction of the catalyst.

\section{Acknowledgment}

Thanks are due to A. Broersma (State University of Utrecht) for performing the TG experiments and to M. C. Mittelmeijer-Hazeleger (University of Amsterdam) for recording the TPR profiles. This study was supported by the Netherlands Foundation for Chemical Research (SON) with financial aid from the Netherlands Organization for the Advancement of Pure Research (ZWO).

\section{Literature Cited}

Andreikov, E. I.; Skorokhod, V. V.; Rus'yanova, N. D. Kinet. Katal. 1973. 14, 1189.

Dadyburjor, D. B.; Jewur, S. S.; Ruckenstein, E. Catal. Rev. Sci. Eng. 1979, 19, 293.

Dillen, A. J. Van Ph.D. Thesis, Utrecht, The Netherlands 1977

Fenin, V. M.; Shvets, V. A.; Kazanskll, V. B. Kinet. Katal. 1971, 12, 1255.

Goldwasser, M. R.; Trimm, D. L. Ind. Eng. Chem. Prod. Res. Dov. 1978, $18,27$.

Hirota, K.; Kera, Y.: Teratanl, S. J. Phys. Chem. 1968, 72, 3133.

Hanke, W.; Blenert, R.; Jerschkewitz, H. G. Z. Anorg. Allg. Chem. 1975. 414, 109.

Hughes, M. F.; Hill, G. R. J. Phys. Chem. 1955, 59, 388.

Kera, Y.; Hirota, K. J. Phys. Chem. 1969, 73, 3973.

Kera, Y.; Kuwata, K. Bull. Chem. Soc. Jpn. 1979, 52, 1268.

Marshneva, V. I.; Boreskov, G. K.; Sokolovskli, V. D. Kinet. Katal. 1972, 13 1209.

Roozeboom, F.; Fransen, T.; Mars, P.; Gellings, P. J. Z. Anorg. Allg. Chem. 1979, 449, 25; Part 1.

Roozeboom, F.; Medema, J.; Gellings, P. J. Z. Phys. Chem. (Frankfurt am Main) 1978, 111, 215; Part 2.

Roozeboom, F.; Mittelmeljer-Hazeleger, M. C.; Moullin, J. A.; Medema, J.; de Beer, V. H. J.; Gellings, P. J. J. Phys. Chem. 1980, 84, 2783; Part 3. Roozeboom, F.; Cordlingley, P. D.; Gellings, P. J., J. Catal., 1981, 68, 464; Part 5.

Simard, G. L.; Steger, J. F.; Arnott, R. J.; Siegel, L. A. Ind. Eng. Chem. $1955,47,1424$.

Stasevich, V. P.; Korneichuk, G. P.; Skorbllina, T. G.; Shaprinskaya, T. M. Kinet. Katal. $1969,10,1317$.

Shaprinskaya, T. M.; Korneichuk, G. P.; Stasevich. V. P. Kinet, Katal. 1870 $11,139$.

Tilley, R. J. D.; Hyde, B. G. J. Phys. Sollds 1970, 31, 1613.

Willigen, J. H. H. G. Van; Kruidhot, H.; Dahmen, E. A. M. F. Talanta 1971, 18 450.

Received for review July 15,1980 Accepted January 7, 1981

\title{
Butynediol Synthesis. A Kinetic Study ${ }^{1}$
}

\author{
S. S. Kale, R. V. Chaudharl, and P. A. Ramachandran \\ National Chemical Laboratory, Pune 411 008, India
}

\begin{abstract}
A kinetic study of ethynylation of formaldehyde over copper acetylide catalyst prepared form malachite green was carried out in a stirred slurry reactor. The reaction was found to be zero order with respect to acetylene and 0.4th order with respect to formaldedhye. The rate of reaction was found to be retarded in the presence of product butynediol. A Langmuir-Hinshelwood type rate model has been proposed which explains the fractional order with respect to formaldehyde and also the product inhibition effect. The reaction rate constant $k_{1}$ and adsorption equilibrium constants of formaldehyde and butynediol $K_{\mathrm{B}}$ and $K_{\mathrm{p}}$ obtained at $70^{\circ} \mathrm{C}$ were $2.921 \times 10^{-3} \mathrm{~cm}^{3} / \mathrm{g} \mathrm{s}$, $951 \mathrm{~cm}^{3} / \mathrm{mol}$, and $1500 \mathrm{~cm}^{3} / \mathrm{mol}$, respectively.
\end{abstract}

\section{Introduction}

The major route for the commercial manufacture of 2-butyne-1,4-diol is by the reaction of acetylene and aqueous formaldehyde in the presence of copper complex catalysts. This process is also known as the Reppe process in which copper acetylide supported on mineral carriers such as silica gel is used as a catalyst. The stoichiometric reaction is

$$
\begin{gathered}
\mathrm{C}_{2} \mathrm{H}_{2}+\mathrm{HCHO} \rightarrow \underset{\text { propargyl alcohol }}{\mathrm{HC} \equiv \mathrm{C}-\mathrm{CH}_{2} \mathrm{OH}} \\
\mathrm{HC} \equiv \mathrm{C}-\mathrm{CH}_{2} \mathrm{OH}+\mathrm{HCHO} \underset{\text { HOCH }}{\rightarrow}-\mathrm{C} \equiv \mathrm{C}-\mathrm{CH}_{2} \mathrm{OH} \\
\mathrm{C}_{2} \mathrm{H}_{2}+2 \mathrm{HCHO} \rightarrow \text { butynediol }
\end{gathered}
$$

\footnotetext{
${ }^{1}$ NCL Communication No. 2515.
}

After the discovery of Reppe et al. (1943), many different catalyst systems have been suggested for this reaction and the major product is butynediol. The various catalysts used are summarized in Table I. Most of the investigations summarized in Table I are concerned with the process for butynediol and only a few attempts to study the kinetics of the reaction systematically have been made. Gelperina et al. (1967) studied the kinetics of this reaction using a silica gel supported copper acetylide catalyst and have proposed a kinetic model. Kirchner (1970) has found that the catalyst prepared from malachite green, a naturally occurring copper ore, is much more active than the conventional catalysts. In the present work we report the kinetics of this reaction using this active catalyst (malachite green). The effect of different variables such as stirring speed, catalyst loading, partial pressure of acetylene, and concentration of formaldehyde has been studied and the absence of diffusional resistence is verified. A rate equa- 